\title{
KARAKTERISTIK SIFAT TARIK DAN MODE PATAHAN KOMPOSIT POLYESTER BERPENGUAT SERAT TAPIS KELAPA
}

\author{
I Made Astika* dan I Gusti Komang Dwijana* \\ *Jurusan Teknik Mesin Fakultas Teknik, Universitas Udayana \\ Kampus Bukit Jimbaran, Bali 80362 \\ email: imdastika@yahoo.com
}

\begin{abstract}
The purpose of this study is to investigate the mechanical properties i.e. tensile strength of composites coconut filter fiber. In the future this material can be used to replace the wood, bamboo and gipsun which are high price and lower water resistance.

The research material made with coconut filter fiber as reinforcement and matrix resin unsaturated polyester (UPRs) type Yukalac BQTN 157, with 1\% hardener types MEKPO (Methyl Ethyl Ketone Peroxide) and fiber treatment by $0.5 \% \mathrm{KMnO}_{4}$. Production methods are poltrusion and the variations of fiber volume fraction are 20,25 and 30\% and fiber length are 5, 10 and 15 $\mathrm{mm}$. Testing of mechanical properties is tensile test (ASTM D3039-76)

The results of research show that the longer of fiber and the bigger of fiber volume fraction, the higher of tensile strength are obtained. The fracture mode are overload, debonding, pullout and crack deflection
\end{abstract}

Keywords : composites, coconut filter fiber, tensile strength, fracture mode

\section{Pendahuluan}

Serat penguat komposit yang umum beredar dan sering digunakan adalah fiberglass, namun harganya cukup mahal dan tidak ramah lingkungan dimana serat gelas tersebut tidak dapat terdegradasi secara alami serta menghasilkan gas $\mathrm{CO}$ dan debu yang berbahaya bagi kesehatan jika didaur ulang (Taurista dkk, 2003). Selain itu Wambua, dkk (2003) mengungkapkan bahwa beberapa dekade terakhir perhatian dunia telah bergeser dari material tunggal menuju konsep material komposit serat dan matrik polimer yang dalam hal ini menggunakan serat alam. Serat alam ini bisa didapat dari tanaman berserat, dengan memanfaatkan serat alam yang bersifat ramah lingkungan.

Mekanisme penguat komposit yang mengalami pergeseran dari penggunaan serat sintetis menuju serat alami yang disebabkan efek limbah serat sintetis yang tidak dapat terurai secara alami tersebut juga dijadikan alternatif karena sifat mekanik cukup memadai untuk aplikasi pada struktur dengan pembebanan yang tidak terlalu tinggi, mudah didapat dan berlimpah serta dapat diproduksi dengan menanam tanaman yang dapat menghasilkan serat tersebut. Walaupun tidak sepenuhnya bergeser, namun penguat serat alam menggantikan serat sintetis adalah sebuah langkah bijak dalam menyelamatkan kelestarian lingkungan dari limbah yang dibuat dan keterbatasan sumber daya alam yang tidak dapat diperbarui.

\section{Dasar Teori}

2.1 Komposit

Suatu material komposit merupakan suatu material yang kompleks dimana terkomposisikan dari dua material atau lebih yang digabungkan/disatukan secara bersamaan pada skala makroskopik membentuk suatu produk yang berguna, yang didesain untuk menghasilkan kualitas maupun sifat terbaik. Penguat biasanya bersifat elastis, dan mempunyai kekuatan tarik yang baik namun tidak dapat digunakan pada temperatur yang tinggi, sedangkan matrik biasanya bersifat ulet, lunak dan bersifat mengikat jika sudah mencapai titik bekunya. Kedua bahan yang mempunyai sifat berbeda ini digabungkan untuk mendapatkan satu bahan baru (komposit) yang mempunyai sifat yang berbeda dari sifat partikel penyusunnya (Jacobs, 2005)

Di dalam komposit dapat tebentuk interphase yaitu fase diantara fase matrik dan penguat yang dapat timbul akibat interaksi kimia antara fase matrik dan fase penguat. 


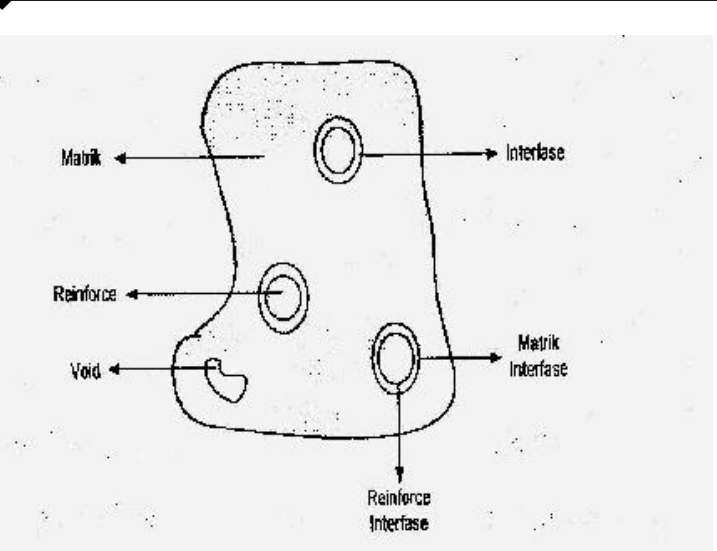

Gambar 1. Fase-fase kalam Komposit. Sumber: Jacobs, 2005

Semakin berkembangnya teknologi memungkinkan komposit dapat didesain sedemikian rupa sesuai dengan karakteristik material yang diinginkan sehingga dapat dibuat menjadi lebih kuat, ringan dan kaku. Dengan beberapa kelebihan tersebut, menyebabkan komposit banyak diaplikasikan dalam peralatan-peralatan teknologi tinggi di bidang industri, transportasi dan konstruksi bangunan. Karena komposit adalah kombinasi sistem resin dan serat penguat, maka sifat-sifat yang dimiliki komposit adalah kombinasi dari sifat sistem resin dan serat penguatnya, seperti grafik berikut :

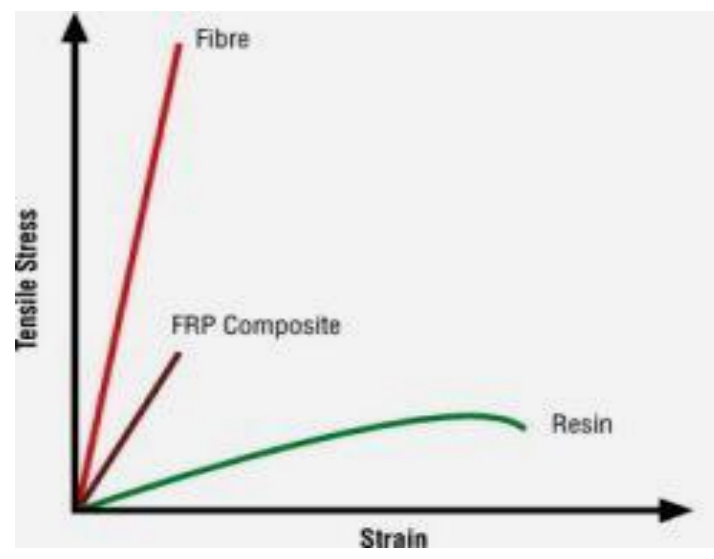

Gambar 2. Grafik hubungan strain-tensile stress dari komposit. (Sumber: Gibson,1994)

\subsection{Serat Alami}

Serat alami (natural fiber) merupakan serat yang bersumber langsung dari alam (bukan merupakan buatan atau rekayasa manusia). Serat alami biasanya didapat dari serat tumbuhan seperti serat bambu, serat pohon pisang, serat nanas dan lain sebagainya. Biasanya sebelum digunakan sebagai penguat dalam komposit, serat alami mendapat perlakuan terlebih dahulu dengan menggunakan cairan kimia seperti $\mathrm{NaOH}$,
$\mathrm{KMnO}_{4}$ dan lainnya. Hal ini bertujuan untuk mengurangi kadar air dan wax (lapisan minyak) dalam serat dan mengakibatkan permukaan lebih kasar sehingga akan meningkatkan ikatan dengan matrik yang digunakan. Perlakuan alkali serat berpengaruh secara signifikan terhadap kekuatan dan modulus tarik komposit serat kenaf acak - polyester. Kekuatan dan modulus tarik tertinggi diperoleh untuk komposit dengan perlakuan alkali serat selama 2 jam (Jamasri dkk, 2005).

Penelitian dan penggunaan serat alami berkembang dengan sangat pesat dewasa ini karena serat alami banyak mempunyai keunggulan dibandingkan serat buatan (sintetic) seperti beratnya lebih ringan, dapat diolah secara alami dan ramah lingkungan. Serat alami juga merupakan bahan terbaharukan dan mempunyai kekuatan dan kekakuan yang relatif tinggi dan tidak menyebabkan iritasi kulit (Oksman dkk, 2003). Keuntungan-keuntungan lainnya adalah kualitas dapat divariasikan dan stabilitas panas yang rendah. Hal yang paling menonjol dari serat alami adalah ramah lingkungan dan mudah didapat. Dua sifat dasar tersebut membuat banyak ilmuan tertarik untuk meneliti dan mengembangkan kegunaan serat alami. Disamping keunggulan tersebut, serat alami juga mempunyai kekurangan antara lain dimensinya tidak teratur, kaku, rentan terhadap panas, mudah menyerap air dan cepat lapuk (Brahmakumar dkk, 2005).

Penggunaan serat alami sudah merambah ke berbagai bidang kehidupan manusia. Layaknya serat buatan, serat alami juga mampu digunakan dalam aspek yang biasanya menggunakan serat buatan hanya saja dalam penggunaanya terdapat modifikasi untuk menyesuaikan dengan sifatsifat dasar dari serat alami.

\subsection{Serat Tapis Kelapa}

Tapis kelapa terdapat pada pangkal pelepah pohon kelapa yang berfungsi menutupi pelepahnya. Tapis kelapa awalnya digunakan oleh masyarakat tradisional sebagai saringan. Namun dengan adanya saringan kawat dan plastik yang memiliki kerapatan yang lebih merata, tapis kelapa pun mulai ditinggalkan. 


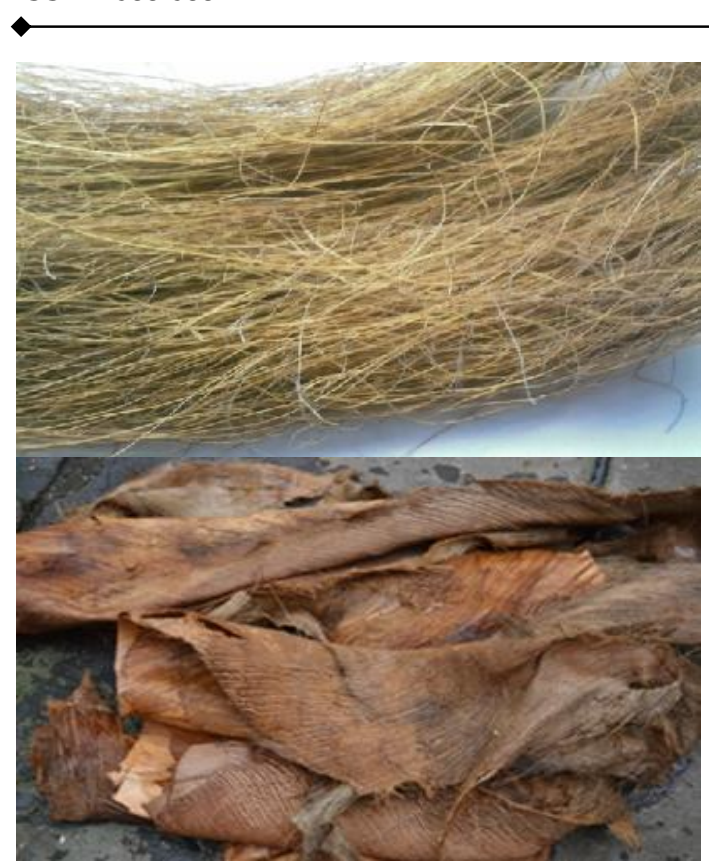

Gambar 3. Tapis dan serat tapis kelapa

Serat ini tersusun dari bahan yang menyerupai bahan pembentuk serabut kelapa. Walaupun jumlah yang dapat dihasilkan dalam satu pohon terbatas namun tapis kelapa mempunyai keunggulan yaitu seratnya sudah tersusun dengan baik secara alami. Susunan serat dari tapis kelapa menyilang antara lapisan serat atas dengan lapisan serat bagian bawah. Karena keunggulan tersebut serat tapis kelapa cocok untuk dijadikan serat alternatif untuk pembuatan komposit.

\section{Metode}

Material yang digunakan pada penelitian ini adalah komposit polymer dengan penguat serat tapis kelapa dan matriks resin Unsaturated-Polyester (UPRs) jenis Yucalac 157 BQTN, campuran $1 \%$ hardener jenis MEKPO (Methyl Ethyl Ketone Peroxide) dan perendaman serat dalam larutan alkali $\mathrm{KMnO}_{4}, 0,5 \%$. Metode produksi adalah poltrusion dengan orientasi serat acak. Desain komposit dengan variasi fraksi volume serat 20,25 dan $30 \%$ dan variasi panjang serat 5,10 dan $15 \mathrm{~mm}$. Sifat mekanis yang diteliti adalah kekuatan tarik (ASTM D 3039-76).

\section{Hasil dan Pembahasan}

Hasil pengujian tarik komposit polyester berpenguat serat tapis kelapa disajikan dalam bentuk grafik seperti berikut

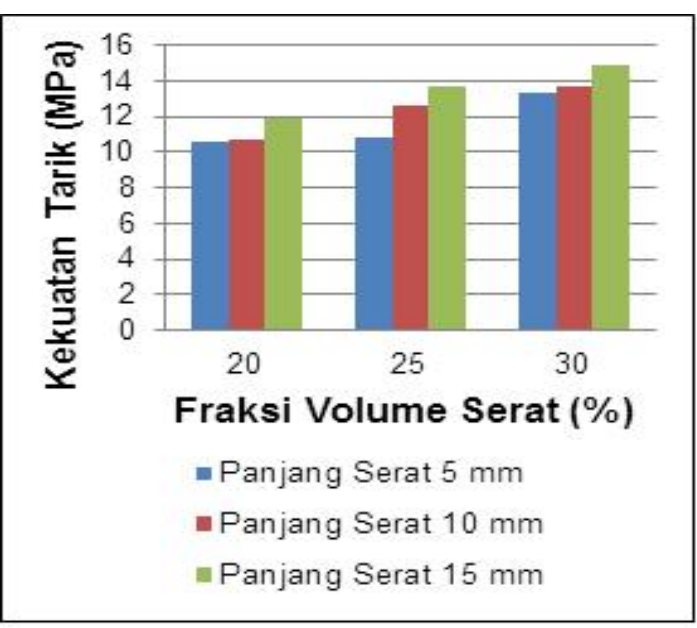

Gambar 4. Grafik hubungan kekuatan tarik, fraksi volume dan panjang serat

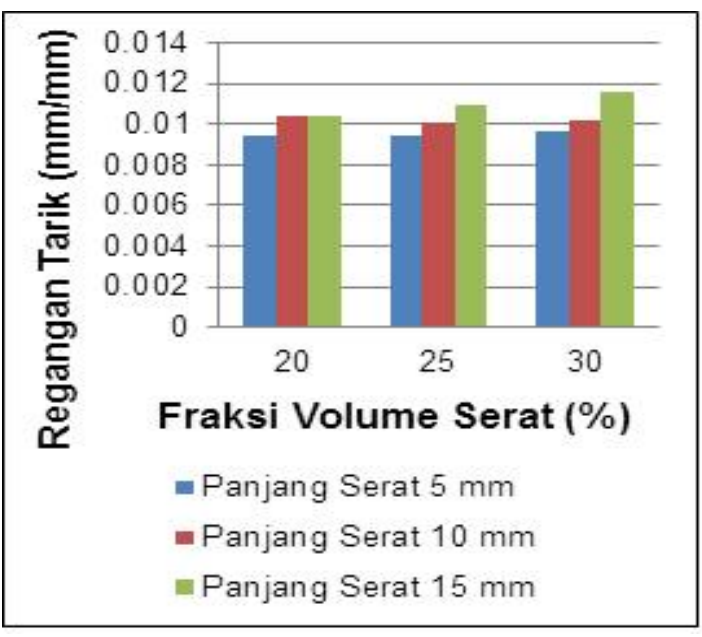

Gambar 5. Grafik hubungan regangan tarik, fraksi volume dan panjang serat

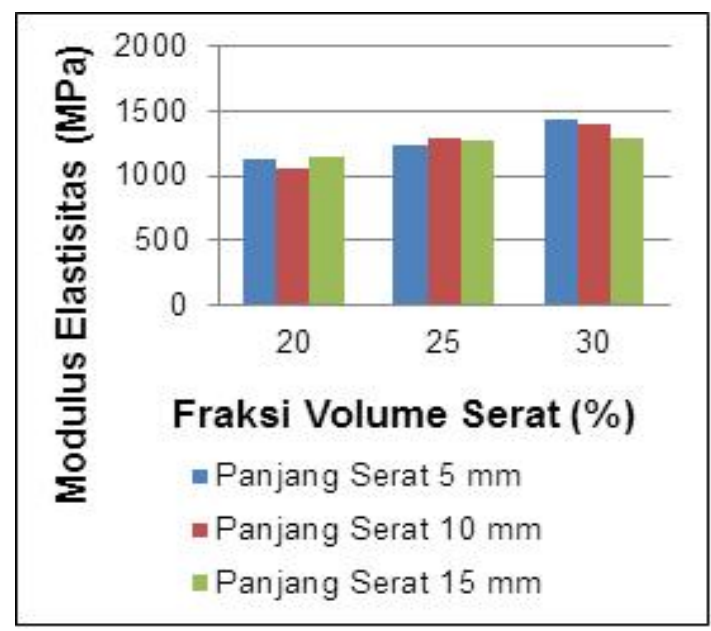

Gambar 6. Grafik hubungan modulus elastisitas, fraksi volume dan panjang serat 
Hubungan antara panjang serat dan fraksi volume serat dengan kekuatan tarik regangan tarik dan modulus elastisitas disajikan pada gambar 4-6. Dari grafik terlihat kekuatan tarik, regangan tarik dan modulus elastisitas yang semakin meningkat seiring dengan bertambahnya fraksi volume dan panjang serat yang digunakan dalam komposit. Peningkatan kekuatan tarik ini disebabkan karena dengan jumlah serat yang semakin banyak maka penguat dalam komposit tersebut akan semakin besar sehingga akan dapat menerima beban tarik yang semakin besar pula. Demikian juga dengan serat yang semakin panjang maka ikatan antara matrik dan serat semakin banyak yang pada akhirnya dapat meningkatkan kekuatan tarik dari komposit tersebut.

Hasil yang sama didapatkan oleh Ikramudin (2007) yang meneliti sifat mekanis dari komposit polyester yang diperkuat dengan serat sabut kelapa dimana semakin besar fraksi volume dan panjang serat yang digunakan dalam komposit, kekuatan tariknya semakin tinggi pula. Bila dibandingkan dengan komposit berpenguat serat sabut kelapa maka komposit berpenguat serat tapis kelapa memiliki kekuatan tarik yang lebih rendah namun bila ditinjau dari fraksi volume dan panjang serat yang digunakan menunjukkan tren yang hampir sama

Menurut Qalbuadi (2007) kekuatan tarik dan lentur tertinggi dari komposit polyester serat tapis kelapa diperoleh pada perlakuan $\mathrm{NaOH} 5 \%$ selama 2 jam. Sedangkan Juniartha (2006) menyatakan bahwa sifat mekanis terbaik komposit serat tapis kelapa/epoxy dihasilkan dengan perlakuan alkali serat dengan persentase $\mathrm{KMnO}_{4}$ sebesar $0,5 \%$. Dari hasil penelitian tersebut di atas menunjukkan bahwa perlakuan permukaan pada serat memperbaiki ikatan serat dengan matriks sehingga menaikkan performa sifat mekanis dari komposit tersebut.

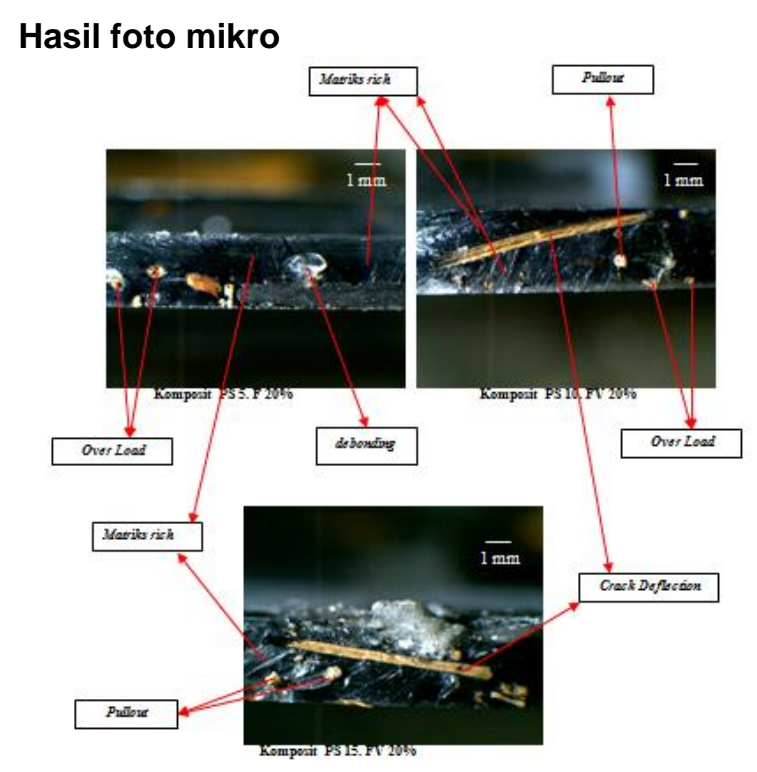

Gambar 7. Foto mikro patahan hasil uji tarif fraksi volume serat $20 \%$

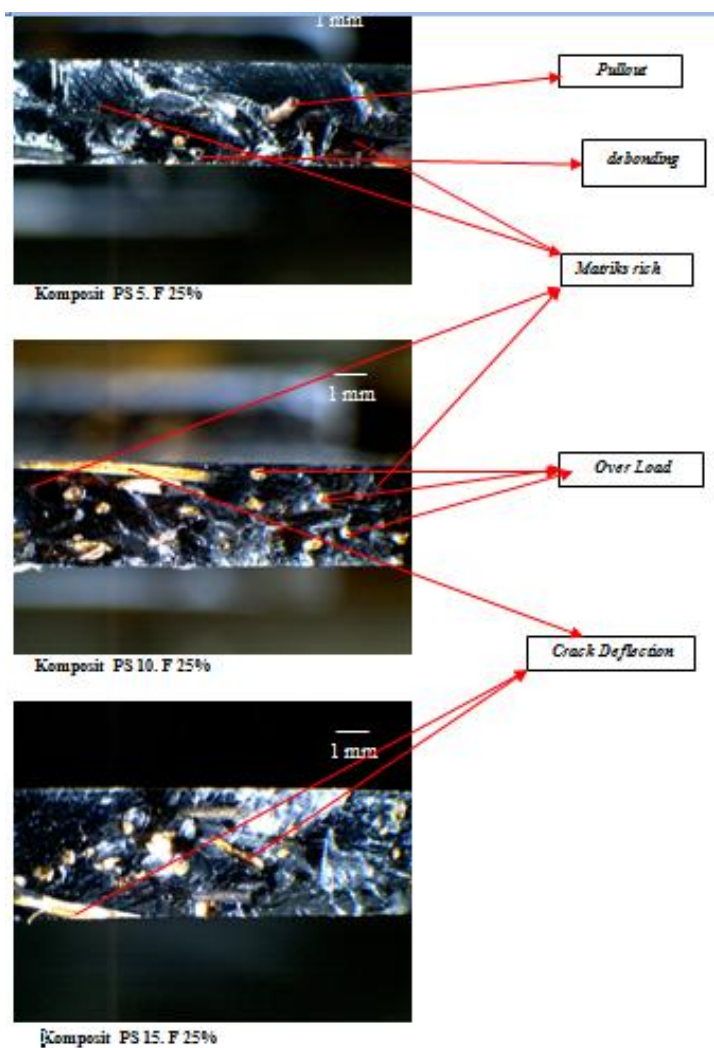

Gambar 8. Foto mikro patahan hasil uji tarik fraksi volume serat $25 \%$ 

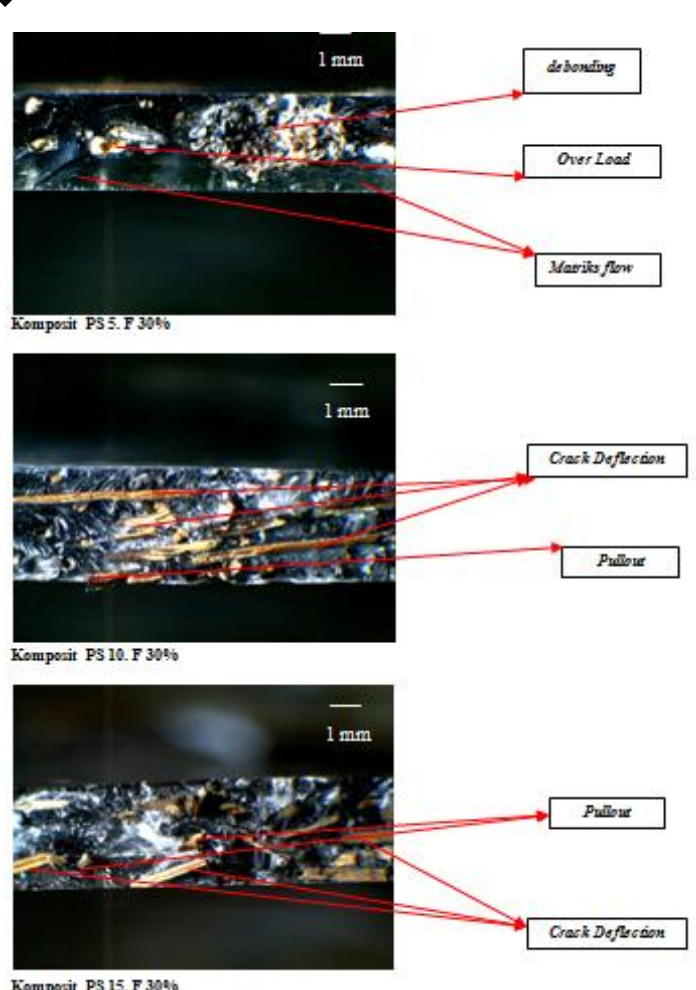

Gambar 7. Foto mikro patahan hasil uji tarik fraksi volume serat $30 \%$

Hasil foto mikro menunjukkan bahwa spesimen dengan fraksi volume 20 dan $25 \%$ untuk semua variasi panjang serat, patahan yang terjadi lebih dikarenakan adanya matrix rich yaitu tidak adanya serat di daerah matrik sehingga menyebabkan komposit menjadi rapuh dan mudah patah pada saat menerim beban. Matrix rich tersebut disebabkan karena kurang banyaknya serat yang digunakan dan juga karena sebaran/distribusi serat dalam komposit tidak merata, sehingga pada saat pencetakan serat berkumpul secara terpisah, sehingga ruang kosong tanpa ikatan matrik dan serat masih banyak ditemui. Mode patahan yang teramati adalah crack deflection, disebabkan karena posisi serat pada permukaan patahan miring mengikuti daerah patahan yang mengakibatkan retakan akan mengikuti alur dari posisi serat yang miring, pullout yang diakibatkan karena ikatan antara serat dengan matriks tidak kuat sehingga serat terlepas/tercabut dari matrik, debonding terjadi karena terlepasnya ikatan serat dari matriks yang menyebabkan terbentuknya lubang/rongga antara matriks dan serat dan overload yaitu putusnya serat yang diakibatkan karena batas kekuatan serat dan ikatan yang kuat antara serat dan matrik. Crack deflection, debonding, pullout dan overload secara merata terlihat pada patahan komposit dengan fraksi volume $30 \%$

\section{Simpulan}

1. Semakin besar fraksi volume dan panjang serat dalam komposit maka tegangan, regangan tarik dan modulus elastisitas semakin tinggi

2. Mode patahan yang teramati adalah patah getas (overload), debonding, pullout dan crack deflection.

\section{Ucapan Terima Kasih}

Ucapan terima kasih disampaikan kepada Universitas Udayana atas bantuan dana yang diberikan melalui hibah penelitian skim Penelitian Fundamental tahun 2014 dengan Surat Perjanjian Penugasan Penelitian No:

103.28/UN14.2/PNL.01.03.00/2014, tanggal 15 Maret 2014

\section{Daftar Pustaka}

ASTM D 3039-76. 1990 "Standard Test Method for Tensile Properties of Fibre Resin Composite". ASTM Standard and Literature References for Composites Material, $2^{\text {ed }}$., American Society for Testing and Materials, Philadelphia, PA.

Brahmakumar, M., Pavithran, C., and Pillai, R.M. 2005, "Coconut fiber reinforced polyethylene composites such as effect of natural waxy surface layer of the fiber on fiber or matrix interfacial bonding and strength of composites", Elsevier, Composite Science and Technology, 65 pp. 563-569.

Gibson, R. F.,1994. "Principles Of Composite Material Mechanics". Mc Graw Hill Book Co.

Ikramuddin Malik, 2007, "Sifat Mekanis Komposit Polimer Berpenguat Serat Sabut Kelapa Orientasi Acak yang diproduksi dengan Teknik Press Hand Lay-Up", Skripsi, Universitas Udayana, Bali

Jacobs James A Thomas F,2005 "Engineering Materials Technology Structures, Processing, Properties and Selection". New Jersey Columbus, Ohio.

Jamasri, Diharjo, K, Handiko, G. W., 2005 "Studi Perlakuan Alkali Terhadap Sifat Tarik Komposit Limbah Serat Sawit Polyester", Prosiding SNTTM IV, Universitas Udayana, Bal.

Juniartha I Made, 2006. "Pengaruh Persentase $\mathrm{KMnO}_{4}$ Sebagai Bahan Perlakuan Serat dan Kompsit EpoxyHardener Terhdap Sifat Mekanis Komposit Serat Tapis Kelapa/Epoxy", 
Skripsi Program Studi Teknik Mesin, Fakultas Teknik Universitas Udayana, Bali.

Oksman, K., Skrifvars, M., Selin, J-F. 2003 , "Natural Fiber as Reinforcement in Polylactic Acid (PLA) Composites", Composites Science and Technology 63, Sciencedirect.com, 1317-1324,
Qalbuadi, 2007. "Analisa Kekuatan Tarik Dan Lentur Komposit Polyester Serat Tapis Kelapa Orientasi Acak Dengan Variasi Waktu Perlakuan NaOH", Skripsi Program Studi Teknik Mesin, Fakultas Teknik Universitas Udayana, Bali. 